\title{
Effect of gibberellic acid and jasmine oil on yield and fruit quality of Ruby Seedless grape cultivar
}

\author{
El-Akad, M.M. ${ }^{1}$, M.K. Rizkalla ${ }^{2}$ and R.A. Ibrahim ${ }^{1 *}$ \\ ${ }^{1}$ Pomology Department, Faculty of Agriculture, Assiut University, Assiut, Egypt \\ ${ }^{2}$ Viticulture Research Department, Horticulture Research Institute, Agriculture Research \\ Center, Giza Egypt
}

\begin{abstract}
This experiment was carried out during two seasons of 2018 and 2019 on 25 years old grapevines of Ruby Seedless cultivar. Head training system was applied by leaving 36 buds per vine (18 fruiting spurs x 2 buds). Eight treatments of GA3 and jasmine oil as a single treatment or combined were evaluated. The experiment aimed to examine the effect of GA3 and jasmine oil on improving yield and berry quality of Ruby Seedless grape cultivar. The studied treatments increased the yield, cluster and berry weight. The best treatment in this term was spraying with GA3 at $20 \mathrm{ppm}$ when berry size about $3 \mathrm{~mm}$ plus jasmine oil at 1.5 $\mathrm{cm}^{3} /$ liter at the beginning of the veraison stage while the control vines gave the lowest values among all treatments. Jasmine oil as a single treatment was the best treatment in respect of TSS\%, acidity, TSS/TA ratio and reducing sugars among all treatments. This study concluded that the beneficial effects of spraying jasmine oil at veraison stage as single or in combined with GA3 at $20 \mathrm{ppm}$ when berry size about $3 \mathrm{~mm}$ to increase yield, berry and cluster weight and improving berry quality of Ruby Seedless grape cultivar.
\end{abstract}

Keywords: Grape; Ruby Seedless; Jasmine oil; Gibberellic acid

\section{Introduction}

The grape is one of the most important fruit crops in the world. The cultivated area has grown rapidly in last few years because of its high return. Ruby Seedless cultivar become one of the most important table grapes both in local and export markets. Small berry size and poor coloration are the most problem facing this cultivar which can cause a major loss in production and quality. Plant growth substances play a major role in plant growth and development. $\mathrm{GA}_{3}$ spraying still used to

\footnotetext{
*Corresponding author: R.A. Ibrahim

Email: rashad_4274@yahoo.com

Received: January 29, 2021;

Accepted: February 22, 2021;

Published: February 25, 2021.
}

increase berry size and thinning bunch berries in seedless cultivars.

The effect of $\mathrm{GA}_{3}$ differed according to the studied cultivar, application date and concentration used (Orth, 1990 and Colapietra et al., 1995). Recently, natural plant extracts are considering the new alternative compounds for improving yield and fruit quality as safety agents for human and environment. Application of plant extracts improves growth and productivity of fruit crops. Jasmonic acid has three categories of biological effects that are stimulation, inhibition and entrainment. It can induce the expression of the ethylene synthesis and promote the generation of ethylene. Jasmonic acid promotes 
degradation of chlorophyll and it also inhibit the photosynthesis of plant (Avanci et al., 2010; Wasternack and Hanse, 2013 and Ashish et al., 2015). I

In climacteric fruits such as apple, Methyl Jasmonate (MJ) application on fruit increases the red color, anthocyanin and $\beta$ carotene and lots of ester compound also accumulate (Rudell et al., 2002).

While in the non-climacteric fruit such as the small fruits (berries) the soluble solid/titratable acidity (SSC/TA) ratio, sucrose and glucose concentrations, and anthocyanin content also increase after MJ application (Wang and Zheng, 2005; Wang et al., 2008). Therefore, the objective of this study is to examine the effect of spraying gibberellic acid $\left(\mathrm{GA}_{3}\right)$ and jasmine oil on yield and fruit quality of "Ruby Seedless" grape cultivar under Assiut climatic conditions.

\section{Materials and Methods}

This investigation was carried out during two successive seasons of 2018 and 2019 on 25 years old grapevines of "Ruby Seedless" cultivar. The selected vines were almost uniform in their vigor and growth and grown at the experimental orchard of the Faculty of Agriculture, Assiut University, where the soil is clay. The vines were trained according to the head training system and pruned during the second week of January. Head training system was applied for leaving total bud load of 36 bud per vine (18 fruiting spurs $\mathrm{x}$ 2 buds). This experiment included eight treatments and 3 vines/treatment. Thus, the total vines used for this experiment were 24 grapevines.

The treatment categories were:

1- Control (spraying water only).

2- Spraying jasmine oil at $1.5 \mathrm{~cm}^{3} /$ liter at the beginning of the veraison stage (when $20 \%$ of berries of $50 \%$ bunch/vine were softened).

3- Spraying GA3 at $10 \mathrm{ppm}$ when shoot length about $20 \mathrm{~cm}$.

4- Spraying GA3 at $10 \mathrm{ppm}+$ jasmine oil at $1.5 \mathrm{~cm} 3 /$ liter.

5- Spraying GA3 at 10 ppm when berry size about $3 \mathrm{~mm}$.

6- Spraying GA3 at $10 \mathrm{ppm}+$ jasmine oil at $1.5 \mathrm{~cm} 3 /$ liter.

7- Spraying GA3 at $20 \mathrm{ppm}$ when berry size about $3 \mathrm{~mm}$.

8- Spraying GA3 at $20 \mathrm{ppm}+$ jasmine oil at $1.5 \mathrm{~cm} 3 /$ liter.

The following parameters were estimated for each treatment.

1- Yield weight (kg).

2- Cluster (bunch) weight (g).

3- Bunch length $(\mathrm{cm})$.

4- Bunch width $(\mathrm{cm})$.

5- Berry length and diameter.

6- 50 berries weight $(\mathrm{g})$.

7- 50 berries juice weight $(\mathrm{g})$

8- Total soluble solids \% (TSS \%) by using a hand refractometer.

9- Total acidity (TA) using titration by $\mathrm{NaOH}$ at $0.1 \mathrm{~N}$ and phenolphethalein as an indicator and expressed as tartaric acid and then TSS/acid ratio was calculated.

10- Reducing sugars according to Lane and Eynon procedure outlined in A.O.A.C. (1985).

The experiment was designed as a complete randomized design. The analysis of variance (ANOVA) was conducted according to Snedecor and Cochran (1972). Means were compared using the least significant differences (LSD) values at $5 \%$ level of the probability.

\section{Results}

\section{(1) Yield and cluster (bunch) characteristics:}


Data presented in Table 1 shows the effect of spraying with $\mathrm{GA}_{3}$ and jasmine oil on yield and cluster characteristics of King Ruby grape cultivar during 2018 and 2019 seasons. It is obvious from the obtained data that spraying jasmine oil single or combined spraying with $\mathrm{GA}_{3}$ significantly increased yield ( $\mathrm{kg} / \mathrm{vine})$. The most effective treatments in this respect were spraying $\mathrm{GA}_{3}$ at $20 \mathrm{ppm}$ (when the berry size reached $3 \mathrm{~mm})+$ jasmine oil followed by $\mathrm{GA}_{3}$ at $20 \mathrm{ppm}$ (when the berry size reached $3 \mathrm{~mm}$ ) compared to untreated (control) vine. The yield weight ( $\mathrm{kg} / \mathrm{vine})$ associated with previous treatments were $9.233 \& 9.11$ and $9.033 \& 9.080 \mathrm{~kg} / \mathrm{vine}$, respectively during the two seasons of study. While the control vine gave the lowest values (5.611 and $6.047 \mathrm{~kg} / \mathrm{vine})$ during the two studied seasons. It is evident that all treatments improved cluster weight. The clusters treated with $\mathrm{GA}_{3}$ at 20 ppm + jasmine oil were the heaviest clusters among all the treatments and the differences between this treatment values and the values of other treatments were significant during the two studied seasons. The clusters weight of this treatment was 692.00 and 665.00 (g) during the two studied seasons, while the lowest values were obtained from the control vine. The recorded values were 342.00 and 330.00 (g) respectively during 2018 and 2019 seasons. Concerning the effect of tested treatments on cluster dimensions during the two studied seasons, it was found that spraying GA3 at $10 \mathrm{ppm}$ alone or combined with jasmine oil was more effective than other treatments. The obtained results showed that the previous treatments gave the highest values of cluster height $(\mathrm{cm})$ and width $(\mathrm{cm})$. The values of cluster height $(\mathrm{cm})$ and width $(\mathrm{cm})$ subjected to these treatments were $29 \& 27.67 \mathrm{~cm}$ and
$14 \& 13.67$ and $30.00 \& 26.00$ and $14 \&$ $12.67 \mathrm{~cm}$, respectively during the two studied seasons. While the lowest cluster length and width values were obtained from the untreated vine. The values associated with this treatment reached $21.33 \& 19.67$ and $9.50 \& 9.33$ during 2018 and 2019 seasons.

\section{(2) Berry physical characteristics:}

Data of various berry physical characteristics as affected by studied treatments during 2018 and 2019 seasons are shown in Table 2. It is clear from the obtained results that all the treatments significantly increased berry length compared to untreated vines. Spraying $\mathrm{GA}_{3}$ at 20 ppm plus jasmine oil gave the highest berry length and diameter. The berry length and diameter $(\mathrm{cm})$ associated with the previous treatment were 1.85, 1.633 as an average of two seasons respectively. On the other side, untreated vines gave the lowest values of 1.400 , $1.267 \mathrm{~cm}$ as an average of the two studied seasons respectively. Concerning the effect of studied treatments on 50 berries weight (g) and 50 berries juice weight (g). Data showed that 50 berries weight and juice weight were affected by all the studied treatments. The highest values in this respect were obtained from the vines treated with $\mathrm{GA}_{3}$ at $20 \mathrm{ppm}$ plus jasmine oil while the untreated vine gave the lowest values. The average values of 50 berry weight associated with these two treatments were 140.4 and $95.5 \mathrm{~g}$ as an average of the two studied seasons. Concerning juice weight, spraying with $\mathrm{GA3}$ at 20 ppm plus jasmine oil gave the highest values $(85.00$ and $74.00 \mathrm{~g})$ comparing with the control vine (58.33 and $53.33 \mathrm{~g})$ respectively during the two studied seasons. 
Table 1. Effect of spraying $\mathrm{GA}_{3}$ and jasmine oil on yield, cluster weight and dimensions of Ruby Seedless grape cultivar during 2018 \&2019 seasons.

\begin{tabular}{|c|c|c|c|c|c|c|c|c|c|c|c|c|}
\hline \multirow{2}{*}{ Treatments } & \multicolumn{3}{|c|}{$\begin{array}{l}\text { Yield weight } \\
\text { (kg/vine) }\end{array}$} & \multicolumn{3}{|c|}{$\begin{array}{c}\text { Cluster weight } \\
\text { (g) }\end{array}$} & \multicolumn{3}{|c|}{$\begin{array}{c}\text { Cluster length } \\
(\mathrm{cm})\end{array}$} & \multicolumn{3}{|c|}{$\begin{array}{l}\text { Cluster width } \\
\text { (cm) }\end{array}$} \\
\hline & 2018 & 2019 & Mean & 2018 & 2019 & Mean & 2018 & 2019 & Mean & 2018 & 2019 & Mean \\
\hline Control & 5.611 & 6.047 & 5.829 & 342.0 & 330.0 & 336.0 & 21.33 & 19.67 & 20.50 & 9.50 & 9.33 & 9.42 \\
\hline Jasmine oil (at veraison stage) & 6.555 & 6.667 & 6.611 & 370.3 & 370.0 & 370.2 & 22.33 & 21.00 & 21.67 & 11.67 & 12.33 & 12.00 \\
\hline $\mathrm{GA}_{3} 10$ ppm (shoot length $20 \mathrm{~cm}$ ) & 6.120 & 6.167 & 6.143 & 375.7 & 398.3 & 387.0 & 30.00 & 26.00 & 28.00 & 14.00 & 12.67 & 13.33 \\
\hline $\begin{array}{l}\left.\mathrm{GA}_{3} 10 \mathrm{ppm} \text { (shoot length } 20 \mathrm{~cm}\right)+ \\
\text { Jasmine oil (at veraison stage) }\end{array}$ & 6.513 & 6.715 & 6.614 & 405.3 & 375.7 & 390.5 & 29.00 & 27.67 & 28.33 & 14.00 & 13.67 & 13.83 \\
\hline $\mathrm{GA}_{3} 10 \mathrm{ppm}$ (berry size $3 \mathrm{~mm}$ ) & 7.407 & 7.700 & 7.553 & 568.3 & 570.0 & 569.2 & 23.67 & 23.33 & 23.50 & 12.33 & 12.33 & 12.33 \\
\hline $\begin{array}{l}\left.\mathrm{GA}_{3} 10 \mathrm{ppm} \text { (berry size } 3 \mathrm{~mm}\right)+ \\
\text { Jasmine oil (at veraison stage) }\end{array}$ & 7.767 & 8.365 & 8.066 & 675.0 & 518.3 & 596.7 & 25.33 & 22.00 & 23.67 & 14.00 & 12.00 & 13.00 \\
\hline $\mathrm{GA}_{3} 20 \mathrm{ppm}$ (berry size $3 \mathrm{~mm}$ ) & 9.033 & 9.080 & 9.057 & 648.7 & 558.3 & 603.5 & 27.00 & 26.00 & 26.50 & 13.33 & 13.00 & 13.17 \\
\hline $\begin{array}{l}\left.\mathrm{GA}_{3} 20 \mathrm{ppm} \text { (berry size } 3 \mathrm{~mm}\right)+ \\
\text { Jasmine oil (at veraison stage) }\end{array}$ & 9.233 & 9.110 & 9.172 & 692.0 & 665.0 & 678.5 & 28.50 & 26.33 & 27.42 & 13.67 & 12.67 & 13.17 \\
\hline New L.S.D 0.05 & 1.093 & 1.173 & & 75.04 & 10.59 & & 2.742 & 2.24 & & 1.793 & 1.499 & \\
\hline
\end{tabular}


Table 2. Effect of spraying $\mathrm{GA}_{3}$ and jasmine oil on berry length, berry diameter, 50 berry weight and 50 berry juice weight of Ruby Seedless grape cultivar during 2018 \&2019 seasons.

\begin{tabular}{|c|c|c|c|c|c|c|c|c|c|c|c|c|}
\hline \multirow{2}{*}{ Treatments } & \multicolumn{3}{|c|}{ berry length(cm) } & \multicolumn{3}{|c|}{ berry diameter $(\mathrm{cm})$} & \multicolumn{3}{|c|}{50 berry weight (g) } & \multicolumn{3}{|c|}{50 berry juice weight (g) } \\
\hline & 2018 & 2019 & Mean & 2018 & 2019 & Mean & 2018 & 2019 & Mean & 2018 & 2019 & Mean \\
\hline Control & 1.433 & 1.367 & 1.400 & 1.333 & 1.200 & 1.267 & 101.0 & 90.0 & 95.5 & 58.33 & 53.33 & 55.83 \\
\hline Jasmine oil (at veraison stage) & 1.633 & 1.500 & 1.567 & 1.433 & 1.367 & 1.400 & 121.0 & 95.0 & 108.0 & 63.33 & 61.67 & 62.50 \\
\hline $\begin{array}{l}\text { GA3 } 10 \text { ppm (shoot length } 20 \\
\mathrm{~cm} \text { ) }\end{array}$ & 1.667 & 1.633 & 1.650 & 1.467 & 1.267 & 1.367 & 97.30 & 123.3 & 110.3 & 71.67 & 58.33 & 65.00 \\
\hline $\begin{array}{l}\text { GA3 } 10 \text { ppm (shoot length } 20 \\
\mathrm{~cm} \text { ) + Jasmine oil (at veraison } \\
\text { stage) }\end{array}$ & 1.733 & 1.600 & 1.667 & 1.533 & 1.500 & 1.517 & 119.2 & 111.7 & 115.4 & 78.33 & 53.33 & 65.83 \\
\hline $\mathrm{GA}_{3} 10 \mathrm{ppm}$ (berry size $3 \mathrm{~mm}$ ) & 1.900 & 1.467 & 1.683 & 1.600 & 1.267 & 1.433 & 129.3 & 125.0 & 127.2 & 65.00 & 70.00 & 67.50 \\
\hline $\begin{array}{l}\text { GA3 } 10 \text { ppm (berry size } 3 \mathrm{~mm})+ \\
\text { Jasmine oil (at veraison stage) }\end{array}$ & 1.833 & 1.600 & 1.717 & 1.600 & 1.500 & 1.550 & 132.8 & 130.0 & 131.4 & 75.00 & 76.67 & 75.83 \\
\hline $\mathrm{GA}_{3} 20 \mathrm{ppm}$ (berry size $3 \mathrm{~mm}$ ) & 1.833 & 1.700 & 1.767 & 1.500 & 1.567 & 1.533 & 140.0 & 125.0 & 132.5 & 85.00 & 67.00 & 76.00 \\
\hline $\begin{array}{l}\text { GA3 } 20 \text { ppm (berry size } 3 \mathrm{~mm} \text { ) + } \\
\text { Jasmine oil (at veraison stage) }\end{array}$ & 1.933 & 1.767 & 1.850 & 1.700 & 1.567 & 1.633 & 149.2 & 131.7 & 140.4 & 85.00 & 74.00 & 79.50 \\
\hline New L.S.D 0.05 & 0.110 & 0.1448 & & 0.145 & 0.134 & & 9.19 & 6.84 & & $17.85 * *$ & 7.36 & \\
\hline
\end{tabular}


Table 3. Effect of spraying $\mathrm{GA}_{3}$ and jasmine oil on TSS\%, TA\%, TSS/TA ratio and reducing sugars $\%$ of Ruby Seedless grape cultivar during $2018 \& 2019$ seasons.

\begin{tabular}{|c|c|c|c|c|c|c|c|c|c|c|c|c|}
\hline \multirow{2}{*}{ Treatments } & \multicolumn{3}{|c|}{ T.S.S \% } & \multicolumn{3}{|c|}{ TA \% } & \multicolumn{3}{|c|}{ TSS/TA ratio } & \multicolumn{3}{|c|}{ Reducing sugars \% } \\
\hline & 2018 & 2019 & Mean & 2018 & 2019 & Mean & 2018 & 2019 & Mean & 2018 & 2019 & Mean \\
\hline Control & 18.27 & 19.00 & 18.63 & 0.507 & 0.490 & 0.498 & 36.06 & 38.78 & 37.42 & 14.67 & 15.48 & 15.07 \\
\hline Jasmine oil (at veraison stage) & 18.80 & 19.80 & 19.30 & 0.473 & 0.463 & 0.468 & 39.73 & 42.74 & 41.24 & 15.09 & 16.60 & 15.84 \\
\hline GA3 10 ppm (shoot length $20 \mathrm{~cm}$ ) & 17.23 & 18.53 & 17.88 & 0.527 & 0.515 & 0.521 & 32.72 & 35.99 & 34.36 & 13.35 & 14.95 & 14.15 \\
\hline $\begin{array}{l}\text { GA3 } 10 \text { ppm (shoot length } 20 \mathrm{~cm} \text { ) + Jasmine oil (at } \\
\text { veraison stage) }\end{array}$ & 18.33 & 17.60 & 17.97 & 0.507 & 0.527 & 0.517 & 36.20 & 33.42 & 34.81 & 14.63 & 14.15 & 14.39 \\
\hline GA3 10 ppm (berry size $3 \mathrm{~mm}$ ) & 17.07 & 17.73 & 17.40 & 0.627 & 0.618 & 0.623 & 27.24 & 28.68 & 27.96 & 13.22 & 13.72 & 13.47 \\
\hline $\begin{array}{l}\text { GA3 } 10 \text { ppm (berry size } 3 \mathrm{~mm} \text { ) + Jasmine oil (at } \\
\text { veraison stage) }\end{array}$ & 17.17 & 19.00 & 18.08 & 0.607 & 0.570 & 0.588 & 28.30 & 33.34 & 30.82 & 13.55 & 15.41 & 14.48 \\
\hline GA3 20 ppm (berry size $3 \mathrm{~mm}$ ) & 17.40 & 16.70 & 17.05 & 0.623 & 0.653 & 0.638 & 27.91 & 25.56 & 26.74 & 13.62 & 13.53 & 13.57 \\
\hline $\begin{array}{l}\text { GA3 } 20 \text { ppm (berry size } 3 \mathrm{~mm} \text { ) + Jasmine oil (at } \\
\text { veraison stage) }\end{array}$ & 18.00 & 17.53 & 17.77 & 0.493 & 0.523 & 0.508 & 36.50 & 33.52 & 35.01 & 14.28 & 13.89 & 14.08 \\
\hline New L.S.D 0.05 & 0.399 & 0.391 & & 0.017 & 0.0173 & & 0.982 & 1.11 & & 0.493 & 0.747 & \\
\hline
\end{tabular}


(3) Berry chemical characteristics:

Data presented in Table 3 shows the effect of tested treatments on TSS\%, total acidity\% (TA), TSS/TA ratio and reducing sugars\%. It could be demonstrated that spraying jasmine oil as a single treatment significantly improved fruit quality in terms of total soluble solids, total acidity, TSS/TA ratio and reducing sugars comparing with untreated vine and other treatments. The results took similar trend during the two studied seasons. The most effective treatment in this respect was spraying jasmine oil followed by untreated vines (control).

The results revealed that spraying the vines with jasmine oil produced the highest total soluble solids values (18.80 \& 19.80\%), lowest total acidity $(0.473 \& 0.463)$ highest TSS/TA ratio (39.73 \&42.74) and highest reducing sugars (15.09 \&16.60\%) during the two studied seasons respectively. While $\mathrm{GA}_{3}$ at $20 \mathrm{ppm}$ gave the lowest $\mathrm{TSS} \%$ (17.40 \& 16.70) highest TA (0.623 \& $0.653)$ lowest TSS/TA ratio $(27.91 \&$ 25.56) and lowest reducing sugars (13.62 \& 13.53) as average during 2018 and 2019 seasons, respectively.

Discussion and Conclusion
$\mathrm{GA}_{3}$ still used for seedless grape production to increase cluster and berry weight. $\mathrm{GA}_{3}$ is very effective for enhancing fruit development in seedless grapevine cultivars through its important role in cell elongate stimulation, enhancing the water absorption and stimulating protein biosynthesis which lead to increase the cluster length as well as berry weight and size. The effect of $\mathrm{GA}_{3}$ depends on the concentration used and date of the treatments (Perez et al., 2000 and Casanova et al., 2009).

The results of the current study are on line with those obtained by Hussein et al. (1986), Ahmed (1988), Shaaban et al. (1989), Mansour (1994), Abd El-Ghany (2000), Dokoozlian and Peacock (2001), Selim (2007), El-Salhy et al. (2009) and Abu-Zahra (2010). They reported that treated grapevine with $\mathrm{GA}_{3}$ increased yield, cluster and berry weight while it decreased TSS\%, sugars and increased the total acidity.

Recently, using natural oils is the new alternative compounds for improving yield and fruit quality. Jas, such as methyl jasmonate, jasmonic acid and other derivatives are referred to as jasmine a kind of plant 
endogenous hormones. Generally, jasmonic acid has three categories of biological effects that are stimulation, inhibition and entrainment. It can induce the expression of the ethylene synthesis and promote the generation of ethylene (Creelman and Mullet, 1995, 1997).

This results are on line with those obtained by Wang et al. (2017), ElKenawy (2018), Gil-Munoz et al. (2018), Garcia-Pastor et al. (2019) and Mohamed et al. (2019) who reported that yield weight, berry attributes, cluster measurements, total soluble solids, anthocyanin content and reducing sugars increased while the acidity decreased by MJ treatment.

According to the previous results, it could be recommended that spraying Ruby Seedless grape vine with jasmine oil as single treatment at the beginning of the veraison stage or spraying $\mathrm{GA}_{3}$ at $20 \mathrm{ppm}$ when berry size about $3 \mathrm{~mm}$ plus jasmine oil $1.5 \mathrm{~cm}^{3} /$ liter at the beginning of the veraison to improve yield, cluster weight, berry weight and berry quality.

\section{References}

Abd El-Ghany, A.A. (2000) 'Effect of shoot topping, paclobotrazol and gibberellic acid application on fruit quality of Thompson Seedless grapevines' Assiut J. of Agric. Sci., 31 (2): pp. $49-57$.

Abu-Zahraa, T.R. (2010) 'Berry size and Thompson Seedless as influenced by the application of gibberellic acid and cane girdling' Pak. J. Bot., 42 (3): pp. 1755 1760.

Ahmed, F.F. (1988) 'Effect of gibberellic acid concentrations number of application and time of spraying on yield and ripening of white Banaty Seedless grapes (Vitis vinifera L.)' Minia J. Agric. Res. \& Dev. Vol. 10, No. 2, pp. 791-810.

Ashish, R.; V. Tyothilakshmi; K.P. Hitendra, P. Ramesh, M. Axel and V.S. Ramesh 'Upregulation of jasmonate biosynthesis and jasmonateresponsive genes in rice leaves in response to a bacterial pathogen mimic' Funct. Integr. Genomics, 15: pp. 363-373.

Association of Official Agricultural Chemist (1985) 'Official Methods of Analysis. A.O.A.C. $14^{\text {th }}$ Ed' 
Published by A.O.A.C., Washington, D.C., USA.

Avanci, N.C.; D.D. Luche, G.H. Goldman and M.H.S. Goldman (2010) 'Jasmonates are phytohormones with multiple functions, including plant defense and reproduction' Genet. Mol. Biol., 9: pp. 484-505.

Casanova, L.; R. Casanova; A. Moret and M. Agusti (2009) 'The application of gibberellic acid increases berry size of "Emperatriz" seedless grape' Spanish Journal of Agricultural Research, 4: pp. 919-927.

Colapietra, M.; L. Tarricone and G. Tagliente (1995) 'Effects of gibberellic acid and cluster thinning on the qualitative characteristics of table grape Centennial Seedless' Rivista di Frutticoltura edi ortofloricoltura 57 (5): pp. 65-70.

Creelman, R.A. and J.E. Mullet (1995) 'Jasmonic acid distribution and action in plants: regulation during development and response to biotic and abiotic stress' Proc. Natl. Acad. Sci., 92: pp. 41144119.
Creelman, R.A. and J.E. Mullet (1997) 'Biosynthesis and action of jasmonates in plants' Annu. Rev. Plant Physiol. Plant Mol. Biol., 48: pp. 355-581.

Dokoozlian, N.K. and W.L. Peacock (2001). 'Gibberellic acid applied at bloom reduces fruit set and improves size of Crimson Seedless table grapes' Hort. Science, 36 (4): pp. 706-709.

El-Kenawy, M.A. (2018) 'Effect of spraying jasmonic acid, girdling and their combination on growth, yield and fruit quality of Crimson Seedless grapevine' Egypt. J. Hort., 45 (1): pp. 25-37.

El-Salhy, A.M.; K.I. Ahmed-Amin; A.A.B. Masoud and A.A. Abozeed (2009) 'Effect of berry thinning, CPPU spraying and pinching on cluster and berry quality of two grapevine cultivars. Assiut J. of Agric. Sci., 40 (4): pp. 92-107.

Garcia-Pastor, M.; Z. Singh and T. Khurdshid (2018) 'Methyl jasmonate effects on table grape ripening, vine yield, berry quality and bioactive compounds depend 
on applied concentration '

Scientia. Hort. 247: 380-389.

Gil-Munoz, R.; J.I. FernandezFernandez and J. Portu (2018) 'Methyl jasmonate effect on proanthocyanin content in Monastrell and Tempranillo grapes and wines' Eur. Food Res. Technol., 244: pp. 611-621.

Hussein, A.A.M.; N.M.G. AbdelHameed; G.M. Nour and A.A. Moustafa (1986) 'Response of Roumi Red grapevines to application of $\mathrm{CCC}$ and $\mathrm{GA}_{3}$. Annals' Agric. Sci., Fac. Agric., Ain shams Univ., Cairo, Egypt, 31 (1): pp. 637-650.

Mansour, A.E.M. (1994) 'Application of gibberellic acid and cycocel on berries development and productivity of Thompson Seedless grapevines' Minia J. Agric. Res. \& Dev. Vol. 16: 323334.

Mohamed, A.K.A.; K.I. Ahmed-Amen, M.M. Shaaban; A.S.A. Gaser and E.A. Abdulfadl (2019) 'Effect of spraying some compounds on berry quality and antioxidants content of three red grape cultivars' J. Sohag Agric. Sci., 1: pp. 17-34.

Orth, C.H.F. (1990) 'Effect of spraying or dipping Muscat Seedless with gibberellic acid at different flowering stage on berry set and berry size' Deciduous Fruit Grower, 40 (11): pp. 428-432.

Perez, F.J.; C. Vionic and J. Retamales (2000) 'Bioactive gibberellins in seeded and seedless grapes: identification and changes in content during berry development. Am. J. Enol. Vitic, 51: pp. 315318.

Rudell, D.R.; J.P. Mattheis; X. Fan and J.K. Fellman (2002) 'Methyl jasmonate enhances anthocyanin accumulation and modifies production of phenolics and pigments in Bfuji apples'. J. Am. Soc. Hort. Sci., 127: pp. 435-441. Selim, A.A. (2007) 'Response of Flame Seedless grapes to some improving treatments under Assiut environments. M.Sc. Thesis, Fac. Agric., Assiut Univ., Egypt.

Shaaban, E.A.; M.M. Tanahy and M.M. Nageib (1989) 'Effect of $\mathrm{GA}_{3}$ and Vapor-Gard on yield and fruit 
quality of Thompson Seedless

grapevine' Assiut J. of Agric. Sci., $20(1): 3-13$.

Snedecor, G.W. and W.G. Cochran (1972) 'Statistical Methods' Iowa State University, Ames, USA

Wang, S.Y. and W. Zheng (2005) 'Preharvest application of methyl jasmonate increases fruit quality and antioxidant capacity in raspberries' Int. J. Food Sci. Technol., 40: pp. 187-195.

Wang, S.Y.; L. Bowman and M. Ding (2008) 'Methyl jasmonate enhances antioxidant activity and flavonoid content in blackberries (Rubus sp.) and promotes antiproliferation of human cancer cells' Food Chem., 107: pp. 12611269.

Wang, W.; M. Khalil-Rehman; J. Feng and J.M. Tao (2017) 'The effect of pre-harvest methyl jasmonate treatment on the selected volatile compounds and endogenous hormones in the pulp of grape berries' J. Plant Biochem. Physiol., 5 (2): pp. 192-199.

Wasternack, C. and B. Hanse (2013) 'Jasmonates: biosynthesis, perception, signal transduction and action in plant stress response, growth and development.'An update to the 2007 review in annals of Botany. Ann. Bot., 111: pp. 1021-1058. 